\title{
Scientists split on US smallpox decision
}

[WASHINGTON] Reversing a position it took as a member of the World Health Organization (WHO) in 1996, the Clinton administration announced last week that it would preserve one of the two known stores of live smallpox virus, housed at the Centers for Disease Control (CDC) in Atlanta.

A spokesman for President Bill Clinton said the decision has been taken on the grounds that live virus is essential for the development of antiviral medicines and novel vaccines to protect the population in the event of accidental or terrorist release of smallpox.

According to a White House statement, "[It] reflects our concern that we cannot be entirely certain that after we destroy the declared stocks in Atlanta and Kotsovo [in Russia] we will eliminate all the smallpox virus in existence. We have a responsibility to develop the drug and vaccine tools to deal with any future contingency."

But the announcement has rekindled a long-standing dispute among scientists and public-health officials as to how best to deal with the stores of a virus that causes a disease declared by WHO to be eradicated in 1980, after a 23-year campaign.

The administration said that a report published in March by the Institute of Medicine on the potential research uses of the live virus had influenced its decision. That report concluded that the most "compelling" need for long-term retention "would be for the development of antiviral agents or novel vaccines to protect against a re-emergence of smallpox due to accidental or intentional release". It did not pronounce on the advisability of destroying or keeping the stocks.

The United States and 189 other countries of the World Health Assembly, WHO's governing body, agreed in 1996 that the

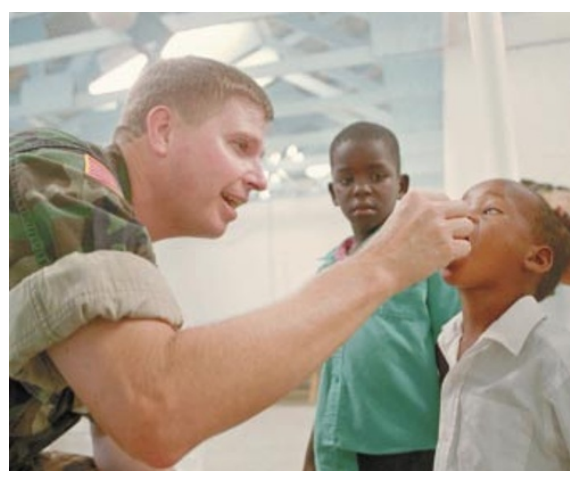

Keep the pox at bay: an unimmunized population would be vulnerable if smallpox re-emerged.

remaining stocks of the virus - housed in high-security facilities at CDC and at the State Centre of Virology and Biotechnology in Kotsovo - should be destroyed this June. But they also agreed that WHO should reaffirm the decision when it meets next month.

In a poll carried out by WHO last year, 74 of 79 countries responding supported destruction. Russia opposed it, saying that valuable research remained to be done on the virus. Britain, France, Italy and the United States were undecided.

Last week's US decision drew criticism from proponents of destruction. They argue that the risks of maintaining the stock outweigh the potential scientific benefits. "Anything that can be done to mitigate against the possibility of that virus being released in the population again should be done," says Donald A. Henderson, director of the Johns Hopkins Center for Civilian Biodefense Studies.

Henderson was formerly a senior science adviser to the Clinton Department of Health and Human Services, and chaired a joint committee of his department and the Department

\section{Radioactive leak at Indian power station}

[NEW DELHI] The Indian Atomic Energy

Commission (AEC) has admitted that eight workers were exposed to "mild radioactivity" last month. The incident happened when about six tonnes of heavy water leaked during the inspection of a coolant channel tube at the Madras Atomic Power Station.

The 220-MW reactor was under routine maintenance when the leak occurred. The incident - rated 1 on the international nuclear events scale of 0 to 7 - is the first since a fire destroyed the control room of a power reactor at Narora, $150 \mathrm{~km}$ from Delhi, six years ago; that rated 3 on the scale.

Neither the AEC nor the Atomic Energy Regulatory Board (AERB) reported the incident. It only came to light only after a newspaper broke the story two weeks later, quoting the workers who had been treated in hospital.

\section{AEC chairman Rajagopalan}

Chidambaram dismissed the event at a press conference in Mumbai (formerly Bombay) last week as of "no safety significance". He claimed that the workers, who were exposed to radioactive tritium, only received three times the amount of radiation they would have normally received in a week.

AERB says the leak was caused by failure of the sealing plug in the equipment used to examine the coolant channel by remote control. It says that a committee has been set up "to investigate the root cause, to review the design of the special seal plug of the inspection equipment, and to suggest remedial measures to avoid recurrence of such incidents." of Defense that examined the issue in $1995 . \mathrm{He}$ charges that a desire to maintain the stock in order to be able to retaliate in the event of a biological attack is behind the administration's reversal, which he claims emanated from the defence department.

Charles Carpenter, a professor of medicine at Brown University in Providence, Rhode Island, who chaired the Institute of Medicine committee, also favours destruction. "I don't feel that we have any reason to try to block its destruction if 99 per cent of the other nations would like to have it destroyed," he told The Washington Post.

But Joshua Lederberg, a professor emeritus at Rockefeller University and a long-time adviser to the US government on biological warfare and infectious-disease issues, applauds the decision. "We know absolutely nothing about the potential for the re-emergence of smallpox or its next cousin," he says.

In the event of an accidental or intentional reintroduction, says Lederberg, an unimmunized population would be extremely vulnerable. "The only thing we have left is to treat it once it has gotten hold" with antiviral drugs that are as yet undeveloped.

Lederberg calls the agreement for stock destruction an unenforceable, "feel-good" measure. It is backed, he says, by "people who aren't in close touch with the microbiology".

Lederberg says countries should preserve stocks under an agreement requiring declaration of possession, inspection of facilities, and research to develop antiviral drugs, and should make provisions for biosafety under the aegis of an international advisory group.

Scientists have also argued that it is impossible to anticipate the questions that might be posed about the virus in 10 or 20 years in areas like human immunology. Similarly, it is not known what tools - perhaps a suitable animal model — might then be available to address them. Without intact virus, they argue, the door to those questions would be shut forever.

In contrast, opponents call the search for antiviral medications impractical and hugely costly, with little chance of success and no adequate animal model available. There are other practical constraints, too, in working with some 450 frozen virus samples housed in a level 4 biosafety laboratory at CDC.

"There are great difficulties in carrying out research with smallpox, especially in terms of the competing priorities we have for the use of our space," says Brian Mahy, director of the Division of Viral and Rickettsial Diseases at CDC. He points out that the centres also need to accommodate research on other dangerous viruses, from Ebola to haemorrhagic fevers. "I think only a limited amount of work on smallpox is likely to be done in future."

Meredith Wadman 